\title{
The time-dependent expression of keratins 5 and 13 during the reepithelialization of human skin wounds
}

\author{
P.Betz ${ }^{1}$, A. Nerlich ${ }^{2}$ J.Tübel $^{1}$, R.Penning ${ }^{1}$, and W. Eisenmenger ${ }^{1}$ \\ ${ }^{1}$ Department of Legal Medicine and ${ }^{2}$ Department of Pathology, University of Munich, Frauenlobstrasse 7a, W-8000 München 2, Germany
}

Received June 19, 1992 / Received in revised form October 5, 1992

\begin{abstract}
Summary. The time-dependent reepithelialization of 55 human surgical skin wounds with a wound age between $8 \mathrm{~h}$ and more than 2 months was investigated by the immunohistochemical localization of cytokeratins 5 and 13. A complete, rebuilt epidermal layer over the wound area was first detectable in a 5-day-old wound, while all wounds of more than 18 days duration contained a completely reepithelialized wound area. Between 5 and 18 days the basal layer of keratinocytes showed - in contrast to normal skin - only some cells positive for cytokeratin 5. In some, but not all lesions with a wound age of 13 days or more, a basal cell layer completely staining for cytokeratin 5 was demonstrable. This staining pattern was found in all skin wounds with a wound age of more than 23 days. The immunohistochemical detection of cytokeratin 13 which can be observed regularly in non-cornifying squamous epithelia provides no information for the time-estimation of human skin wounds, since no significant temporary expression of this polypeptide seems to occur during the healing of human skin wounds.
\end{abstract}

Key words: Reepithelialization - Keratin 5 - Keratin 13 - Wound age - Immunohistochemistry

Zusammenfassung. An 55 chirurgisch versorgten menschlichen Hautwunden mit einer Überlebenszeit zwischen 8 Stunden und über 2 Monaten wurde die wundaltersabhängige Expression von Keratin 5 und 13 während der Reepithelialisierung untersucht. Eine vollständige Dekkung des ursprünglichen Epitheldefektes war erstmals in einer 5 Tage alten Hautwunde zu beobachten, wobei in der Basalzellschicht nur einzelne Cytokeratin 5-positive Zellen nachweisbar waren. Nach 13 Tagen Überlebenszeit war hier erstmals eine vollständige Anfärbbarkeit für Cytokeratin 5 feststellbar, regelhaft war dies nach mehr als ca. 23 Tagen Überlebenszeit der Fall. Nach einem Wundalter von ca. 18 Tagen war die Reepithelialisierung des ursprünglichen Defektes immer vervoll-

This study was supported by grants from the "Deutsche Forschungsgemeinschaft" (grant Ei 209/3-1) and the Friedrich-Baur-Stiftung, University of Munich, Germany

Correspondence to: $\mathrm{P}$. Betz ständigt, auch wenn nicht alle Basalzellen Cytokeratin 5 exprimierten. Die Darstellung von Cytokeratin 13, ein für nicht-verhornendes Plattenepithel typischer Marker, liefert keine Informationen, die für eine Altersbestimmung menschlicher Hautwunden verwertbar wären, da offensichtlich eine relevante temporäre Expression während der Wundheilung in der menschlichen Haut nicht erfolgt.

Schlüsselwörter: Reepithelialisierung - Keratin 5 - Keratin 13 - Wundalter - Immunhistochemie

\section{Introduction}

Cytokeratins (CK) represent a group of intermediate filaments expressed solely in epithelial cells. They can be subdivided into 8 type II (1-8) and 12 type I keratins (9-20) $[10,11,12]$ and 2 cytokeratins in combination (one type I and one type II) form an intermediate filament $[4,21]$.

In the normal epidermal layer the pair ck $5 / 14$ is expressed in the basal cell layer [3] and the pair ck $1 / 10$ is normally restricted to the suprabasal cells [3]. The pair ck 4/13, however, can regularly be observed only in the suprabasal cell layers of non-cornifying epithelium [13].

During wound healing the damaged epidermis is covered by keratinocytes and after reepithelialization these cells differentiate as demonstrated by the temporary expression of certain maturation markers such as involucrin, transglutaminase, and filaggrin [9]. Similarly, the expression of cytokeratins has been reported to be variable during wound healing [9].

The present study was performed to investigate the time-dependent reepithelialization of human skin wounds and in particular the immunohistochemical expression of cytokeratin 5 during wound healing. Furthermore, ck 13 was visualized to prove whether cytokeratins typical for non-cornifying squamous epithelia are temporarily demonstrable during the healing of the epidermis and therefore provide further information useful for a timeestimation of human skin lesions. 


\section{Materials and methods}

The cytokeratins 5 and 13 were visualized in a total of 55 human skin wounds (surgical wounds, stab wounds and lacerations after surgical treatment) with a wound age between $8 \mathrm{~h}$ and 2.5 months by immunohistochemistry. The specimens were obtained and prepared as previously described [1].

After enzymatical pretreatment cytokeratin 5 was visualized using a monoclonal antibody (Laboserv, Gießen, Germany) according to the $\mathrm{ABC}$-method [8]. $\mathrm{Ck} 13$ was detected using a monoclonal antibody (Progen Heidelberg, Germany) according to the APAAP-method [5].

Undamaged skin from the same patients and sections without the inclusion of the primary antibody served as controls.

\section{Results}

\section{Normal skin}

In undamaged skin the basal cell layer of the epidermis and the basal cells of the epithelial surface of skin appendages (sweat gland ducts, hair follicles) showed a strong positive staining for cytokeratin 5 . Superficial cells of the epidermal layer, however, did not react.

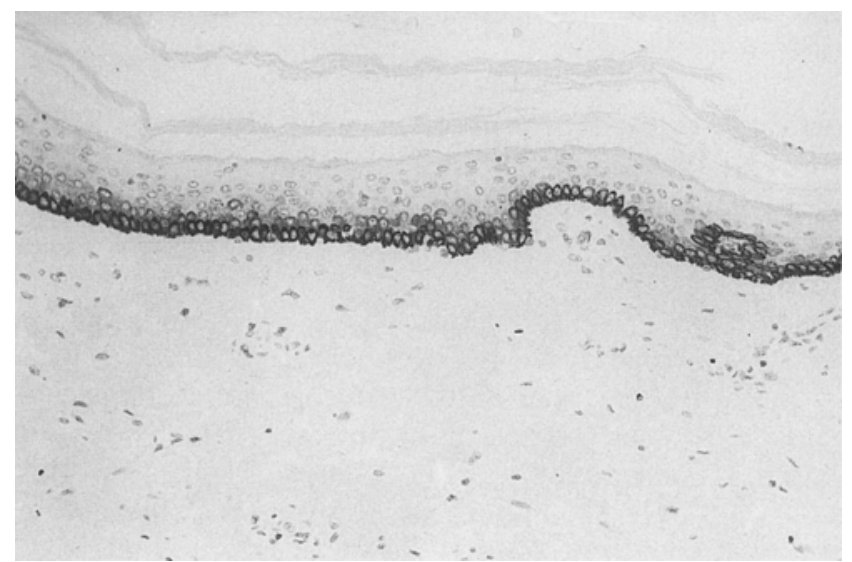

Fig. 1. Normal human skin: the basal cell layer of the epidermis showing a continous staining for cytokeratin 5 (paraffin, $\mathrm{ABC}$ method, $170 \times$ )

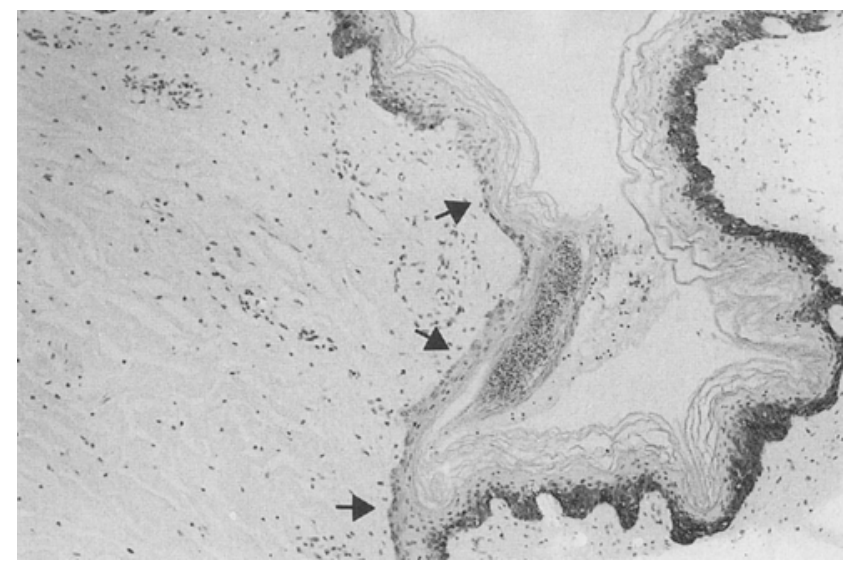

Fig. 2. 8-day-old skin wound: complete reepithelialization of the wound area, but no positive reactivity of the basal cells (arrows) for cytokeratin 5 (paraffin, ABC-method, $70 \times$ )

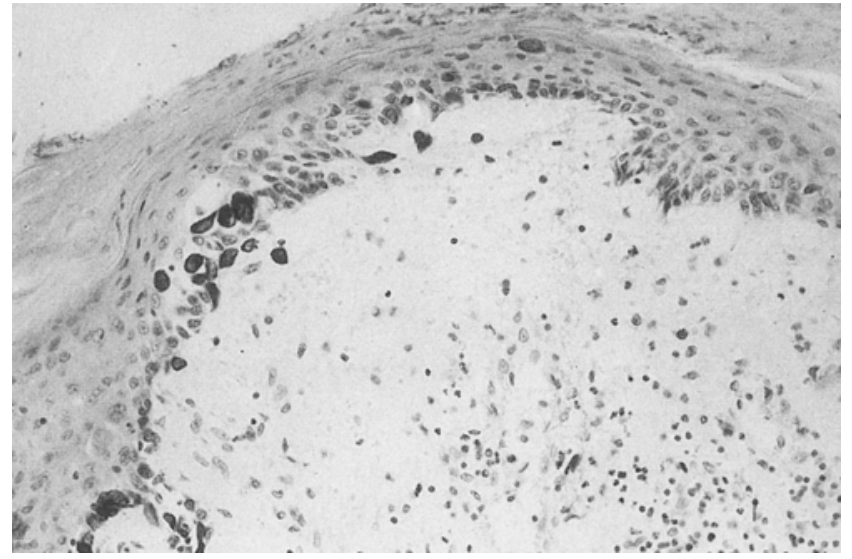

Fig. 3. 11-day-old skin wound: complete reepithelialization; only few basal cells positively stain for ck 5 (paraffin, ABC-method, $170 \times)$



Fig. 4. 4-week-old skin wound: the total basal cell layer of the rebuilt epidermis stains positively for ck 5 (paraffin, ABC-method, $170 \times)$

No reaction was obtained in the keratinocytes of the epidermis after staining with the antibody against ck 13. The epithelium of sweat gland ducts, however, stained positively.

\section{Skin wounds}

In the newly forming epidermal layer of incompletely reepithelialized skin wounds, keratinocytes positive for ck 5 were first detectable approximately 3 days after wounding. In a 5-day-old skin lesion of the head a complete reepithelialization was observed first, but only few cells of the basal cell layer reacted positively for ck 5 . A positive staining of the complete newly formed basal cell layer of the epidermis occurred first in a 13-day-old wound and all lesions with a duration of approximately 25 days or more showed such a staining pattern. In 26 out of 42 cases $(62 \%)$ with a wound age between 5 and 25 days the reepithelialization was not yet completed. In $19 \%$ ( 8 out of 42 cases) a complete reepithelialization was demonstrable, but the basal cell layer of the newly formed epidermis showed varying amounts of keratinocytes positive for ck 5 . The remaining 8 cases $(19 \%)$ 
were characterized by an epidermal layer with positive reactivity of the total basal cell layer covering the wound area.

Even though the first complete reepithelialization was seen in a surgically treated laceration of the head (78-year-old male) a tendency indicating advanced reepithelialization in the head region in comparision to the trunk or the extremities, could not be established.

Significant differences in wound healing dependent on the individual's age did not occur in our series.

Cytokeratin 13 could not be observed in the epidermal layer during wound healing in significant amounts. In one specimen (wound age 11 days) very few keratinocytes seemed to show a weak positive reactivity.

\section{Discussion}

During wound healing a new epidermal layer is formed by migration and proliferation of keratinocytes derived from undamaged skin of the wound edges and from nearby localized skin appendages $[2,7,14,15,19,22]$. The migrating keratinocytes stem from the suprabasal cell layer of the epidermis [17] and are assumed to possess contractile properties [6].

After completion of epithelial proliferation and migration the keratinocytes undergo differentiation which is monitored by the expression of certain maturation markers and a typical pattern of various cytokeratins.

Mansbridge and Knapp [9] demonstrated an increase in the synthesis of ck 6 and 16 and a reduction of ck 1 during the first $8.5 \mathrm{~h}$ in skin wounds (suction blisters) of volunteers. A residual synthesis of ck 6 and 16 was seen $48 \mathrm{~h}$ after tape stripping of the skin while ck 1,2 and 10 were overproduced. On the third day after wounding, a tongue of keratinocytes displaying regenerative maturation markers such as involucrin, transglutaminase, and filaggrin extended across the floor of the suction blisters. This kind of lesion was also studied by Ortonne et al. [17] on the abdominal skin of volunteers. These authors localized a $67 \mathrm{kDA}$ cytokeratin polypeptide and found that keratinocytes derived from suprabasal cell layers started to migrate to the wound centre 2 days after wounding. Keratinocytes of the basal cell layer, however, did not stain for the antibody against the $67 \mathrm{kDa}$ cytokeratin and were not observed in the wound area during the period of investigation ( 3 days) indicating that basal cells apparently do not migrate at this point in time [17]. In former studies, however, it had been assumed that basal cell of the epidermis were also able to migrate [22].

Although the observations by Mansbridge and Knapp [9] as well as Ortonne et al. [17] were obtained from human individuals, only wounds of the epidermis, but not of the dermis had been examined. It has, however, been assumed that the epidermal migration is inhibited by the destruction of dermal structures [19], so that these observations cannot easily be transferred to forensically relevant skin wounds which show an involvement of the whole epidermis and dermis. Experimental results obtained from animal models also cannot provide sufficient data due to methodological reasons with respect to the assumption that biological processes such as wound healing proceed somewhat faster in small animals. This hypothesis is particularly supported by the findings of Ordmann and Gillman [16]. These authors studied the wound healing process in sutured pig skin and reported a reepithelialization of the wound surface within 24 hours, i.e. 4 days before a complete newly formed epidermis was seen in our series.

Since the basal cell layer of the new epithelium first showed a complete positive staining for ck 5 after approximately 13 days survival time, our findings are in accordance with the results of Ortonne et al. [17]. They reported that migrating keratinocytes are derived from suprabasal cell layers and not from the basal cells of the epidermis.

In our series, a complete reepithelialization was first detectable 5 days after wounding, i.e. 3 days before a complete rearrangement of the epithelial basement membrane occurs [1]. This difference can be explained by the observation that epithelial cell seem to synthesize - at least partly - the basement membrane components and therefore appear before basement membrane material is detectable.

Furthermore, our results provide evidence that cytokeratins typical for non-cornifying squamous epithelium such as ck 13 do not occur in normal human skin lesions, in contrast to the regenerating non-cornifying epithelium of the vagina [20]. Thus, this cytokeratin does not represent a useful parameter for a time-estimation during the healing of skin wounds.

In summary, the immunohistochemical localization of ck 5 and 13 provides the following information for the time-estimation of surgical human skin wounds:

1. A complete reepithelialization indicates a post-infliction interval of approximately 5 days or more and can be expected in all cases with a wound age of approximately 19 days or more, but the basal cell layer does not necessarily show a continuous staining for ck 5 .

2. A complete staining for ck 5 in the basal cell layer covering the wound area indicates a duration of approximately 13 days or more and can regularly be expected in lesions with a wound age of at least approximately 23 days.

3. There exists no significant time difference of wound healing dependent on the localization of the wound, even though a somewhat faster reepithelialization of skin wounds localized in regions rich in skin appendages such as the head cannot be excluded.

4. The immunohistochemical detection of ck 13 provides no useful information, since this cytokeratin does not appear during normal human wound healing.

\section{References}

1. Betz P, Nerlich A, Wilske J, Tübel J, Wiest I, Penning R, Eisenmenger W (1992) The time-dependent rearrangement of the epithelial basement membrane in human skin wounds - 
immunohistochemical localization of collagen IV and VII. Int J Leg Med 105:93-97

2. Clark RAF, Lanigan JM, DellaPelle P, Manseau E, Dvorak HF, Colvin RB (1982) Fibronectin and fibrin provide a provisional matrix for epidermal cell migration during wound reepithelialization. J Invest Dermatol 79:264-269

3. Cooper D, Schermer A, Sun TT (1985) Biology of disease. Classification of human epithelia and their neoplasms using monoclonal antibodies to keratins: strategies, applications and limitations. Lab Invest 52:243-256

4. Cooper D, Sun TT (1986) Monoclonal antibody analysis of bovine epithelial keratins. Specific pairs as defined by coexpression. J Biol Chem 261:4646-4654

5. Cordell JL, Falini B, Erber WN, Ghosh AK, Abdulaziz Z, MacDonald S, Pulford AF, Stein H, Mason DY (1984) Immunoenzymatic labeling of monoclonal antibodies using immune complexes of alkaline phosphatase and monoclonal antialkaline phosphatase (APAAP-complex). J Histochem Cytochem 32:219-229

6. Gabbiani G, Ryan GB (1974) Development of a contractile apparatus in epithelial cells during epidermal and liver regeneration. J Submicrosc Cytol Pathol 6:143-157

7. Guo M, Toda K, Grinnell F (1990) Activation of human keratinocyte migration on type I collagen and fibronectin. J Cell Sci 96:197-205

8. Hsu SM, Raine L, Fanger H (1981) A comparative study of the peroxidase-antiperoxidase method and an avidin-biotin complex method for studying polypeptide hormones with radio immunoassay antibodies. Am J Clin Pathol 75:734-739

9. Mansbridge JN, Knapp AM (1987) Changes in keratinocyte maturation during wound healing. J Invest Dermatol 89:253263

10. Mischke D, Wild GA (1987) Polymorphic keratins in human epidermis. J Invest Dermatol 88:191-197

11. Moll R, Franke WW, Schiller DL, Geiger B, Krepler R (1982) The catalog of human cytokeratins: patterns of expression in normal epithelia, tumors, and cultured cells. Cell 31:11-24

12. Moll R (1991) Differenzierung und Entdifferenzierung im Spiegel der Intermediärfilament-Expression: Untersuchungen an normalen, alterierten und malignen Epithelien mit Betonung der Cytokeratine. Verh Dtsch Ges Pathol 75 :446-459
13. Muijen van GNP, Ruiter DJ, Franke WW, Achtstätter Th, Haasnot WHB, Ponec M, Warnaar SO (1986) Cell type heterogeneity of cytokeratin expression in complex epithelia and carcinomas as demonstrated by monoclonal antibodies specific for cytokeratins nos. 4 and 13. Exp Cell Res 162:98-113

14. Oehlert W, Büchner T (1961) Mechanismus und zeitlicher Ablauf der physiologischen Regeneration am mehrschichtigen Plattenepithel und in der Schleimhaut des Magen-Darmtraktes der weiBen Maus. Beitr Pathol Anat 125:373-402

15. O'Keefe EJ, Payne Jr RE, Russell N, Woodley DT (1985) Spreading and enhanced motility of human keratinocytes on fibronectin. J Invest Dermatol $85: 125-130$

16. Ordman LJ, Gillman T (1966) Studies in the healing of cutaneous wounds. I. The healing of incisions through the skin of pigs. Arch Surg 93:857-882

17. Ortonne J-P, Löning T, Schmitt D, Thivolet J (1981) Immunomorphological and ultrastructural aspects of keratinocyte migration in epidermal wound healing. Virchows Arch [A] 392: 217-230

18. Pang SC, Daniels WH, Buck RC (1978) Epidermal migration during the healing of suction blisters in rat skin: a scanning and transmission electron microscopy study. Am J Anat 153:177191

19. Pollack SV (1979) Wound healing: a review. I. The biology of wound healing. J Dermatol Surg Oncol 5:389-393

20. Schaller G (1991) Das Differenzierungsverhalten des menschlichen Vaginalepithels am Beispiel der Keratinexpression. Habilitationsschrift, Universität München

21. Sun TT, Eichner R, Schermer R, Cooper D, Nelson WG, Weiss RA (1984) Classification, expression and possible mechanisms of evolution of mammalian epithelial keratins: a unifying model. In: Levine A, Topp W, Woude G, Watson JD (eds) Cancer Cells. Cold Spring Harbor Laboratory, New York, pp 169-176

22. Winter GD (1972) Epidermal regeneration studied in the domestic pig. In: Maibach H, Rovec DT (eds) Epidermal wound healing. Year Book Medical Publishers, Chicago pp $71-112$ 